\title{
Zircon ages delimit the provenance of a sand extrudite from the Botucatu Formation in the Paraná volcanic province, Iraí, Brazil
}

\author{
VITER M. PINTO ${ }^{1,2}$, LÉO A. HARTMANN ${ }^{2}$, JOÃO O.S. SANTOS ${ }^{3}$ and NEAL J. MCNAUGHTON ${ }^{4}$ \\ ${ }^{1}$ Universidade Federal de Pelotas, Praça Domingos Rodrigues, 02, 96010-040 Pelotas, RS, Brasil \\ ${ }^{2}$ Instituto de Geociências, Universidade Federal do Rio Grande do Sul, \\ Av. Bento Gonçalves, 9500, 91501-970 Porto Alegre, RS, Brasil \\ ${ }^{3}$ Centre for Exploration Targeting, The University of Western Australia, 35, Stirling Highway, Crawley WA 6009, Australia \\ ${ }^{4}$ John de Laeter Centre of Mass Spectrometry, Curtin University of Technology, Kent Street, Bentley, WA 6102, Australia
}

Manuscript received on May 28, 2013; accepted for publication on January 30, 2015

\begin{abstract}
Ion microprobe age determinations of 102 detrital zircon crystals from a sand extrudite, Cretaceous Paraná volcanic province, set limits on the origin of the numerous sand layers present in this major flood basalt province. The zircon U-Pb ages reflect four main orogenic cycles: Mesoproterozoic (1155-962 Ma), latest Proterozoic-early Cambrian (808-500 Ma) and two Palaeozoic (Ordovician- 480 to $450 \mathrm{Ma}$, and Permian to Lower Triassic- 296 to $250 \mathrm{Ma}$ ). Two additional small concentrations are present in the Neoarchean (2.8 to $2.6 \mathrm{Ga}$ ) and Paleoproterozoic (2.0 to $1.7 \mathrm{Ga}$ ). Zircon age peaks closely match the several pulses of igneous activity in the Precambrian Brazilian Shield and active orogeny in Argentina. A main delimitation of the origin of the sand is the absence of zircon ages from the underlying Cretaceous basalts, thus supporting an injectite origin of the sand as an extrudite that emanated from the paleoerg that constitutes the Botucatu Formation.
\end{abstract}

Key words: Botucatu Formation, Brazil, Neoarchean to Palaeozoic ages, provenance, sand extrudite, Zircon U-Pb ages.

\section{INTRODUCTION}

Detrital minerals in sedimentary rocks provide a record of the provenance of the rocks and are a clue to the tectonic processes in the source terranes. Zircon is a prominent component of detrital assemblages, because it is highly refractory and resilient, occurring in nearly all sedimentary deposits and thus providing a critical link between source terranes and the final sedimentary repository (Fedo et al. 2003). The use of detrital zircon U-Pb ages obtained by the sensitive high resolution ion microprobe (SHRIMP)

Correspondence to: Léo Afraneo Hartmann

E-mail:1eo.hartmann@ufrgs.br is a powerful tool in the provenance investigation of sedimentary rocks (Hartmann et al. 2004, 2008, Najman 2006, Santos et al. 2002, 2003).

Sandstone layers (1-5 m thick, 100-500 m large) are very common in the Paraná volcanic province (e.g. Hartmann et al. 2012, 2013) of southeastern South America (mostly Brazil, but also Uruguay, Argentina and Paraguay). There may be up to 120 layers in each stratigraphic column of basalts and rhyodacites of this bimodal province, because a layer is present between nearly every two successive lava flows. Numerous sandstone feeder dikes and sills are also present. The composition of the sandstone is 
mostly quartz (90 vol.\%), feldspar (5\%) and opaque minerals $(5 \%)$, with a chalcedony cement.

We selected a silicified sandstone layer near Iraí, state of Rio Grande do Sul, Brazil, because it is positioned nearly $800 \mathrm{~m}$ above the contact of the volcanic province and the underlying paleoerg (Botucatu Formation). The origin of this layer is likely similar to the many other sandstone layers in the volcanic province, which makes this a most significant study in the realm of sedimentary and volcanic processes in their interaction in a large intraplate basaltic province.

The regional geology presents a major puzzle, with the presence of strongly silicified sandstones intercalated in basalts of a major continental volcanic province. The detrital grains (mostly quartz, some feldspar) are similar to the grains present in the Botucatu Formation paleoerg below the volcanics and no surficial source for the quartz is present in the Serra Geral Group.

The SHRIMP U-Pb analysis of zircon crystals was used to determine the age of the detrital grains with the goal of delimiting the provenance and origin of the sandstone layers in the Paraná volcanic province.

\section{MATERIALS AND METHODS}

The sample of silicified sandstone was collected for SHRIMP studies in a rock cut of BR386 highway, close to Iraí town in the section that continues to Frederico Westphalen (Figs. 1a, 1b, 1c, 1d). The sample is from a sandstone layer that covers the basalt flow dated by Pinto et al. (2011) from the same outcrop. The quartz sandstone has rounded and well selected quartz $(\sim 90 \%)$, orthoclase $(\sim 4 \%)$, plagioclase $(3 \%)$, and muscovite (3\%) with epidote, zircon, apatite, titanite and magnetite as main accessories. The sample weighing $2 \mathrm{~kg}$ was crushed, milled, processed by sieving and heavy liquid and magnetic mineral separation at the Universidade Federal do Rio Grande do Sul laboratories. Zircon was hand-picked at the final stage.

Selected grains were mounted on an epoxy disc with chips of the BR266 zircon standard, ground and polished until nearly half of each grain was removed, and then microphotographed in transmitted and reflected light. For visualization of internal morphology, imaging was performed at the University of Western Australia using a scanning electron microscope (i.e. backscattered electrons). The mount was then cleaned and gold-coated to have a uniform electrical conductivity during the SHRIMP analyses.

The isotopic composition of the zircons was determined with the Curtin University SHRIMP II equipment, using methods described by Compston et al. (1992) and Smith et al. (1998). Circular areas of 20-30 $\mu \mathrm{m}$ were analyzed from morphologically distinct zones chosen within zircon grains and replicate analyses of the BR266 standard in the same epoxy mount. Corrections for common $\mathrm{Pb}$ were made using measured ${ }^{204} \mathrm{~Pb}$ and the $\mathrm{Pb}$ isotopic composition. Results with morethan $1 \%$ commonlead correction were not used to calculate the ages, such as grains C3-5 and D14-4 (Table SI) (Supplementary Material). For each analysis, an initial 60-90 seconds were used to rasterize and remove the gold, avoiding the analysis of common $\mathrm{Pb}$ from the coating. Zircon data are reduced using SQUID (Ludwig 2002). Data were plotted on weighted average using ISOPLOT/ Ex software (Ludwig 1999). The uncertainty in all pooled ages is at the $95 \%$ confidence levels, whereas errors in Table SI are at 1 sigma (\%). Ages older than $1.5 \mathrm{Ga}$ are expressed as weighted mean ${ }^{207} \mathrm{~Pb} /{ }^{206} \mathrm{~Pb}$ age values, and younger ages are based on weighted mean ${ }^{206} \mathrm{~Pb} /{ }^{238} \mathrm{U}$ ratios.

\section{GEOLOGICAL SETTING}

The Paraná volcanic province extends for approximately $917,000 \mathrm{~km}^{2}$ (Frank et al. 2009) near the top of the Paraná Basin (Zalán et al. 1991), only overlain partly by the Bauru Group of sedimentary rocks. The province is made up mostly of the Serra Geral Group of bimodal basalt-rhyodacite rocks (e.g. Pinto and Hartmann 2011). The thickness of lavas in the depocenter of the basin $(100 \mathrm{~km}$ to 


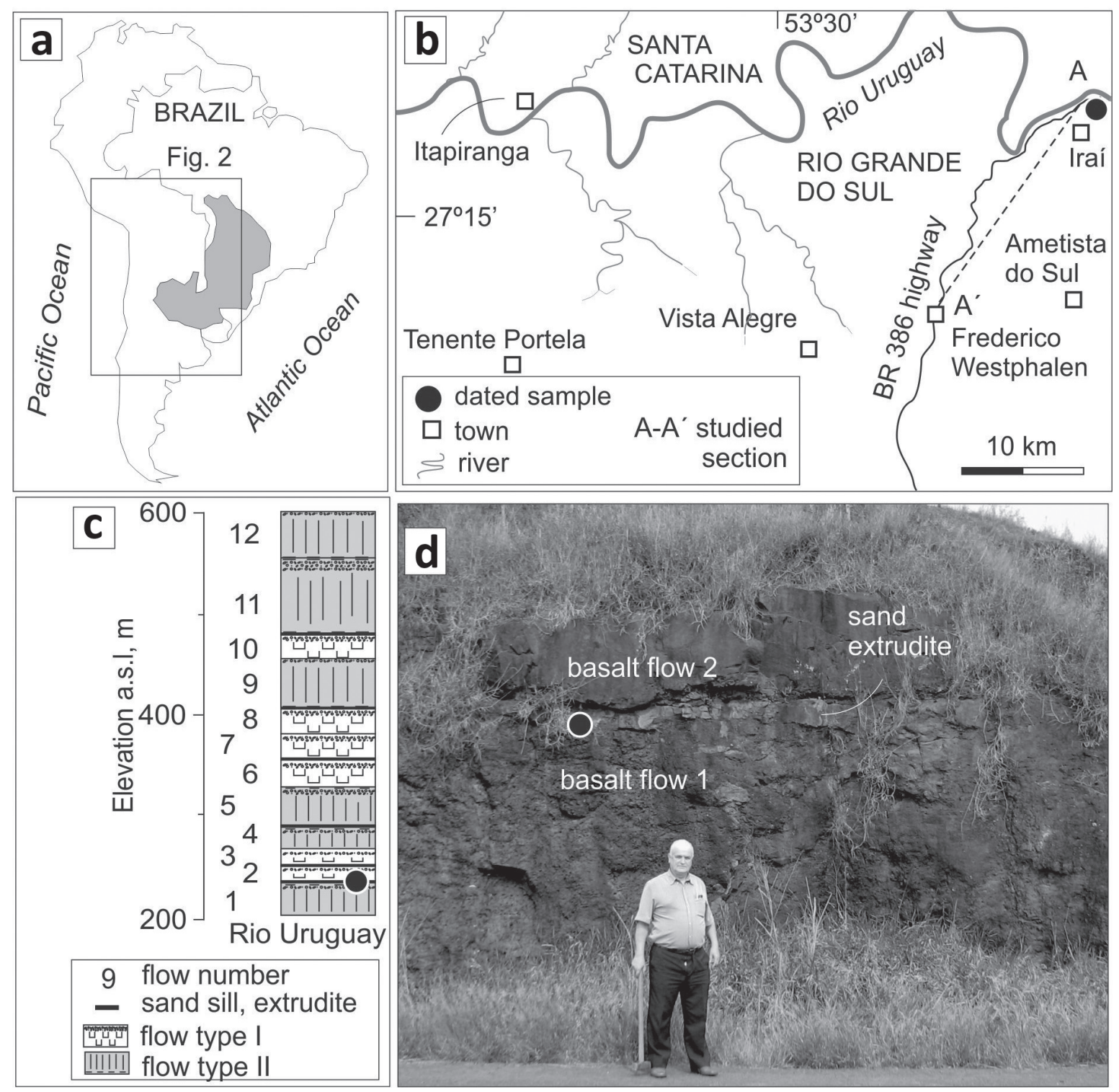

Figure 1 - Location map: a) map of South America and Brazil highlighting the Paraná Basin; b) study region indicating the sampling section; c) location of the collected sandstone in the stratigraphic section; (d) outcrop indicating site of collected sample; flows type 1 and type 2 from Pinto et al. (2011).

the north of the studied outcrop) reaches $1,800 \mathrm{~m}$, corresponding possibly to 120 flows.

The climate seems to have remained arid during the entire event of lava effusion, because the volcanic group is underlain by the aeolian erg deposits of the Botucatu Formation and overlain by sedimentary rocks formed in a desert environment. No evidence of humid climate is registered in lava structure or lava stratigraphy.
Intertrap aeolian sandstone deposits occur on top of the first few lava flows in many sections of the province. Higher up in the volcanic stratigraphy, sandstones with low-angle stratification are common along the entire sequence, both horizontally and vertically. Sandstone dikes and sills are also common; dikes are feeder conduits to the sandstone layers. Although interpreted previously as wind-blown sand deposits over basalt flows, the sandstones are 
now described as an injectite complex made up of a source layer in the paleoerg (Botucatu Formation), an injectite complex of dikes and sills and extrudites at the paleosurface (Hartmann et al. 2012).

In Iraí, a stratigraphic section of 13 basalt lava flows, initiating in Iraí and reaching Frederico Westphalen (Pinto and Hartmann 2011), has the composition of high-Ti near the level of Rio Uruguay (Fig. 1). The lavas evolve into medium-Ti Paranapanema chemical type as defined by Peate et al. (1992) for the entire province. Every lava flow has a strongly silicified sandstone (0.3-1.0 m thick) layer on top and is intruded by thin (0.1-0.3 m) dikes of similar composition. The studied sample was collected from a flat-lying sandstone layer at the bottom of the sequence near Iraí (Figs. 1c, 1d).

The paleoerg Botucatu Formation is distributed over an area larger than 1,500,000 $\mathrm{km}^{2}$ (Scherer and Goldberg 2007), possibly the largest sand sea in Earth history. Both the volcanic rocks and the underlying paleoerg are also present in the Etendeka (Stanistreet and Stollhoffen 1999), the African fragment of the pre-rifting basin. The concordant contact and interlayering of the Botucatu Formation and the Serra Geral Group means that the lavas flowed initally over loose, non lithified dune sand.

The age of volcanism in the province is close to $135 \mathrm{Ma}$, based on Ar-Ar isotopes (Thiede and Vasconcelos 2010), U-Pb zircon SHRIMP(Pinto et al. 2011) and SIMS (Janasi et al. 2011). The duration of lava effusion is commonly considered to be less than one million years. The intimate relationship between the aeolian sandstones and the lava flow deposits, and the lack of regional-scale unconformities within the aeolian package suggest that the Botucatu Formation comprises a shorter time interval, as discussed by Scherer (2000). Therefore, the beginning of Cretaceous age, probably Valanginian, seems more adequate for the onset of aeolian sedimentation in the Botucatu Formation.

The Brazilian Shield underneath the Paraná Basin (Fig. 2) is composed of igneous and metamorphic rocks of the Brasiliano orogenic cycle $(880-500 \mathrm{Ma}$; e.g. Silva et al. 2005) and of the Rio de La Plata craton (mostly Trans-Amazonian Cycle 2.35-2.00 Ga) with lesser Archean rocks (e.g. Hartmann et al. 2000, 2008, Santos et al. 2002).

The regional and local geology require adequate techniques of investigation to solve the puzzle of the presence of quartz sandstone layers on top of basalt flows in the entire province and in Iraí. Zircon dating is considered appropriate.

\section{AgE DATA}

One hundred and two zircon grains were dated by U-Pb SHRIMP II, using between three and five scans for each grain. The sample was divided in two populations named $\mathrm{C}$ and $\mathrm{D}$, with $\mathrm{C} 1-\mathrm{C} 10$ and D11-D25 sub-populations (Table SI). All obtained data are shown in Table SI and representative populations in Figure 3a. The main population (Fig. $3 b$ ) is represented by fifty grains of the Brasiliano Cycle (810-503 Ma) age and the second group is from seventeen grains of Sunsás Cycle (1100-960 Ma) age. Other important groups (Fig. 3c) are ten grains aged $\sim 480-440 \mathrm{Ma}$ (Ordovician) and fourteen zircons aged 280-245 Ma (Permian to Lower Triassic), all magmatic. There are two small populations aged $\sim 2.6$ to $2.8 \mathrm{Ga}$ (Archean, three zircons) and 2.0-1.8 Ga (Paleoproterozoic, four grains). One grain yielded $400 \mathrm{Ma}$, with very high $\mathrm{Th} / \mathrm{U}$ ratio (3.41), but this analysis is discordant on a Concordia diagram.

Backscattered electron images of zircon crystals (Figs. 4a-h) show size variations from 10 to $200 \mu \mathrm{m}$. Some crystals are rounded to subrounded, none shows oscillatory zonation but many have irregular shapes. In general, the elongated crystals with predominantly euhedral, pyramidal terminations, have Permian ages (Figs. 4b, 4h). Some zircon grains display oscillatory zonation, therefore rim and core analyses were undertaken on 10 grains; five of these had similar ages, whereas three recorded early Cambrian to latest 


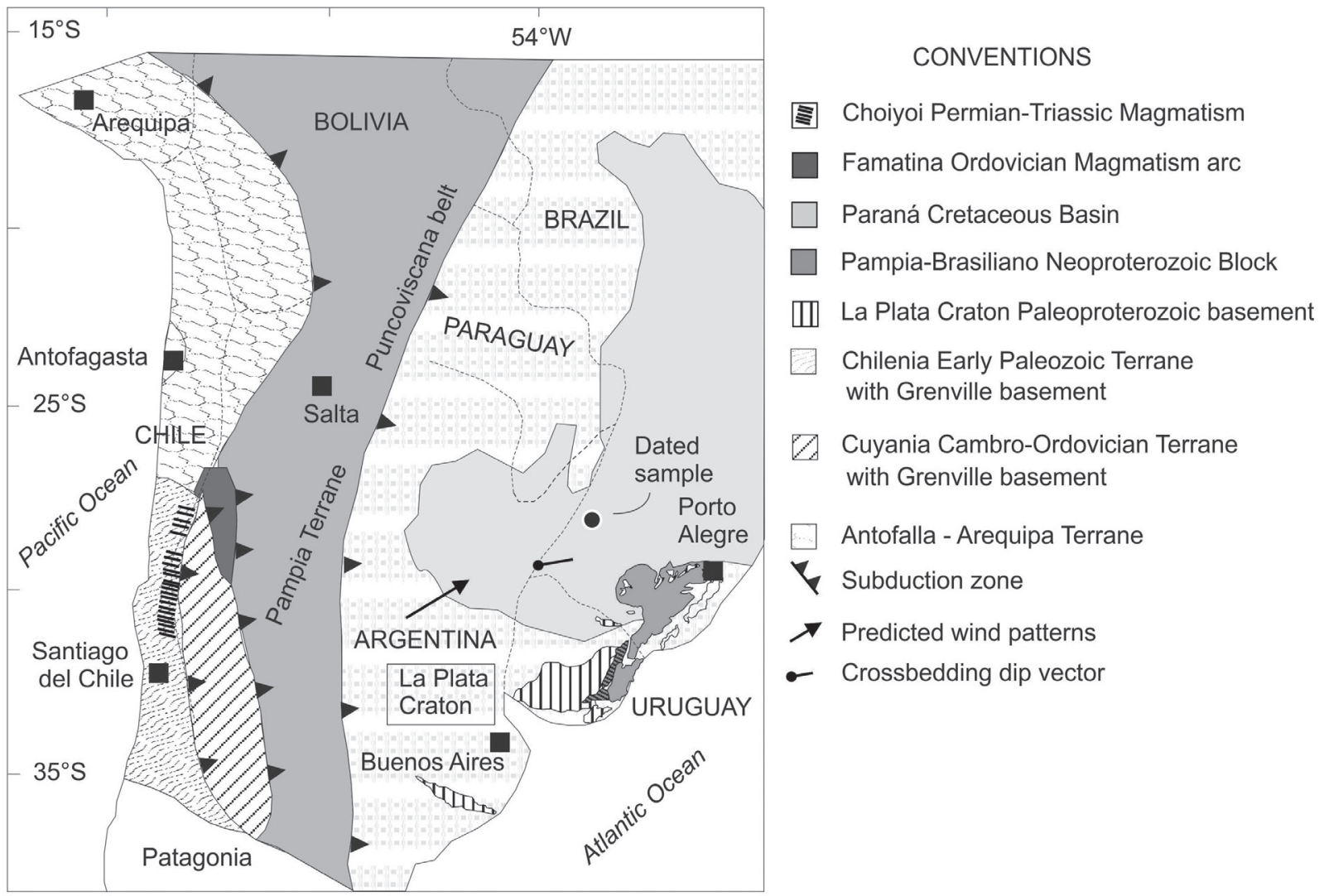

Figure 2 - Geological map of part of South America based on Ramos (2000), Silva et al. (2005), Hartmann et al. (2008), Santos et al. (2002). The map includes wind patterns (Moore et al. 1992) and crossbedding dip vector (Scherer and Goldberg 2007).

Neoproterozoic rims with Mesoproterozoic cores (Fig. 4b) and two had early Neoproterozoic cores.

The $\mathrm{U}$ contents of the studied zircons range between 88 and 1078 ppm and many lie between 200 and $400 \mathrm{ppm}$. Th/U ratios of zircons range between 0.03 and 3.41. Only two analyses resulted in $\mathrm{Th} / \mathrm{U}$ ratios $<0.1$ and these have ages of 560 and $631 \mathrm{Ma}$. These low $\mathrm{Th} / \mathrm{U}$ spots are typical of metamorphic zircon compositions (e.g. Hartmann et al. 2000). On the other hand, the majority of the ratios are $>0.10$, common in magmatic zircon. According to Hartmann and Santos (2004), the low Th/U ratio of metamorphic zircon is due to high $\mathrm{U}$, which causes higher metamictization and faster comminution of the grains, transported and deposited in finer grained rocks such as mudstones. Detrital zircon in sandstones such as the studied sample is a record of magmatic events in the source terrane.

\section{DISCUSSION}

We consider the dated sandstone layer as an extrudite that originated by sand injection from the underlying (800-m deep) paleoerg. Nevertheless, the sand present in the paleoerg needs a provenance evaluation. The direction of sediment transport in aeolian sandstones of the Botucatu Formation (Early Cretaceous of the Paraná Basin) has been interpreted on the basis of cross-strata dip directions. These indicated palaeowind directions and allowed the reconstruction of regional wind patterns in Midwestern Gondwana (Scherer and Goldberg 2007). Due to the reduced thickness of the Botucatu Formation in the outcrop area, in this work, cross-strata dip directions were compiled from data available in the literature, such as the work of Bigarella and Salamuni (1961), Scherer and Goldberg (2007), and predicted wind patterns 

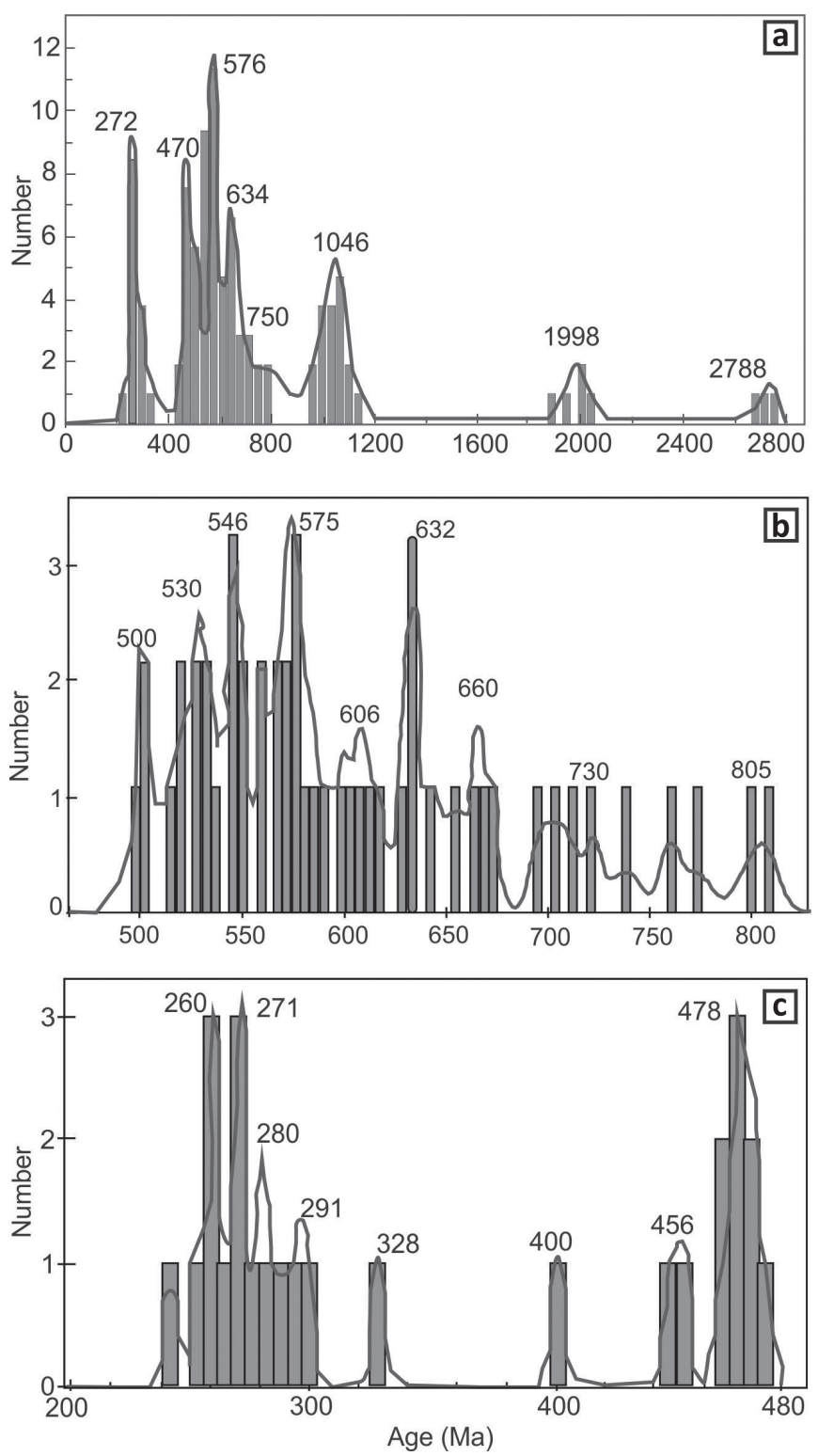

Figure 3 - Frequency histograms and probability curves of zircon $\mathrm{U}-\mathrm{Pb}$ ages, sample VIS1/2 (sandstone). Main age peaks are indicated. a) All ages, from Neoarchean to Lower Triassic; b) Neoproterozoic and Cambrian ages (Brasiliano Orogenic Cycle sources); c) PostCambrian ages dominated by Ordovician (Famatinian sources from the SW) and Permian (Choiyoy sources from SW) ages.

from Moore et al. (1992). Mean vectors were plotted on the map with the "tadpole" symbol and the large arrows show the predicted wind patterns close to the studied area (Fig. 2). In these studies, measurements of cross-strata dip directions in area close to the sample show an average dip direction varying between $\sim 040^{\circ}$ to $100^{\circ}$, indicating that the direction of sediment transport was from southwestern to western (SW/W).

Two remarkable results of the age study of detrital zircons from the sandstone layer on top of a basalt flow are the absence of ages younger than 


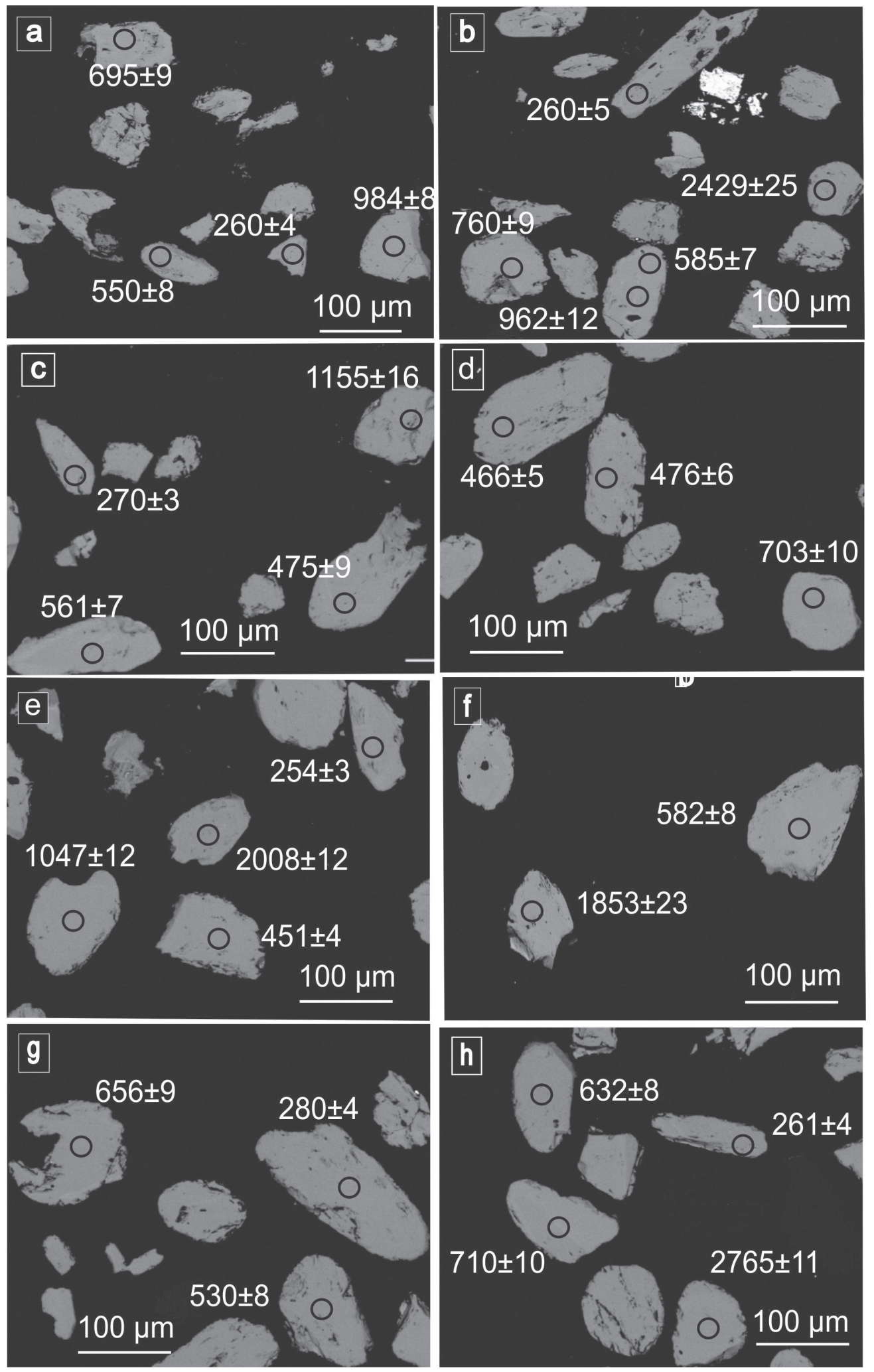

Figure 4 - Backscattered electron images of analyzed zircons, sandstone sample VIS-1/2. Circles indicate position of SHRIMP analyses; U-Pb ages in Ma. 
the Permian to Lower Triassic and the presence of the full spectrum of ages from the southern Brazilian Shield and Argentina. No zircons derived from the Serra Geral Group were recognized, even though an $800 \mathrm{~m}$-section of basalts and rhyodacites underlies the sandstone. The volcanic group did not contribute to the sedimentary budget of the deposited sandstone. A quartz sandstone is not expected to form by desert wind activity in a basin on top of basalts. Just as unlikely is a process of wind blowing sand $800 \mathrm{~m}$ up the plateau from the underlying Botucatu Formation.

In southernmost Brazil, zircon grains from tonsteins intercalated in Permian sedimentary rocks of the Irati and Rio Bonito Formations (Paraná Basin) yielded SHRIMP ages $\sim 290 \mathrm{Ma}$ (Guerra-Sommer et al. 2008). These zircon crystals probably originated in an active and widespread Lower Permian explosive volcanic event in western Gondwana, which is interpreted as the same volcanism that produced the Choiyoi Group in western Argentina. This event is similar to the October 2011 ash-fall that covered southern Brazil after the Puyehue-Cordón Caulle volcano explosion in Chile.

The southern Brazilian Shield is composed of Archean to Paleoproterozoic rocks from the Rio de La Plata craton, but the Neoproterozoic to Cambrian rocks of the Brasiliano Cycle are voluminous.

\section{LA PLATA CRATON}

The ages of Neoarchean (2.66 to $2.77 \mathrm{Ga}$ ) and Paleoproterozoic (1.8-2 Ga) are the minor source in the provenance terranes in this study. The Neoarchean ages occur in detrital zircon in the Brazilian Shield (Hartmann et al. 2008) and in detrital zircons from Punta Mogotes Formation, Mar del Plata terrane, Argentina (Rapela et al. 2011). Trans-Amazonian ages are common in Brazil, Uruguay and Argentina (e.g. Santos et al. 2002, Rapela et al. 2011). There is no register in the sample of Trans-Amazonian ages $(\sim 2.05$ to $2.3 \mathrm{Ga})$ that would be typical of the Tandilla belt (Argentina) and the Piedras Altas terrane (Uruguay) (Santos et al. 2002), to the south of the studied area. The few detrital zircons from the Paleoproterozoic indicate that the Trans-Amazonian block was little exposed when the Paraná Basin was deposited. Because the Paleoproterozoic crust was intensely reworked in the Brasiliano orogenic Cycle, only a small volume is now exposed.

MESOPROTEROZOIC AgeS

Mesoproteozoic ages have been recorded at various locations along the Andean margin (Sunsás Orogeny). Among these, rocks from the Arequipa-Antofalla terrane (e.g. Bahlurg and Hervé 1997), Cuyania terrane (Ramos 2004), Western Sierras Pampeanas (Casquet et al. 2006, Chernicoff et al. 2012) and the Puncoviscana belt (e.g. Escayola et al. 2007) have late and early Mesoproterozoic ages and are interpreted as part of an autochthonous terrane (Schwartz and Gromet 2004).

In Brazil and Uruguay there is little evidence of Mesoproterozoic ages, e.g. Capivarita anorthosite (Chemale et al. 2011) and Sarandi del Y Lineament and Sierra Ballena shear zone (Santos et al. 2002).

\section{Neoproterozoic to CAMBrian Ages}

Few ages lie between 0.8 and $0.7 \mathrm{Ga}$; the main concentration is from 660 to $560 \mathrm{Ma}$ and another from 550 to $500 \mathrm{Ma}$, with highest age peaks at 632 , 575 and $546 \mathrm{Ma}$. These ages are concordant with the geochronological subdivision of the Brasiliano/ Pan-African systems of orogens by Silva et al. (2005) into three systems. The BRASILIANO I had collisional climaxes at ca. $\sim 790$ and 730-700 Ma, recognized in the southwestern domain of the state of Rio Grande do Sul in the São Gabriel terrane (Chemale 2000) (São Gabriel Orogeny, sensu Hartmann et al. 2000) and Embu Terrane (sensu Campos Neto 2000, Cordani et al. 2002) (see Figs. 1, 2 and 3 in Silva et al. 2005). The BRASILIANO II had collisional climaxes at ca. 640-620 Ma and ca. $600 \mathrm{Ma}$, represented by three orogens, extending from close to Montevideo city, 
Uruguay, to northeast of São Paulo city, Brazil, designated from south to north as the Pelotas/ Dom Feliciano, Rio Piên and Ribeira Belt. The BRASILIANO III climaxed at 595-560 and 530$500 \mathrm{Ma}$, with the Araçuaí orogen and Búzios orogen, respectively. They have counterparts presenting similar paroxysmal timing in the adjacent western Tocantins Province (southern Brasilia Belt) and in the Pan-African orogens as observed by Silva et al. (2005). The temporally equivalent Pan-African orogenic stages from Caby (1998) are, respectively, the Early Pan-African (climax at ca. 800-650 Ma), the Main Pan-African 'Episode' (climax at ca. 650$590 \mathrm{Ma}$ ) and the Late Pan-African orogeny with climax at ca. 590-540 Ma.

Some evidence was obtained for juvenile Early Neoproterozoic magmatism by Chernicoff et al. $(2011,2012)$ from Hf isotope determinations in the Pampia terrane (Puncoviscana metasedimentary rocks, Argentina). SHRIMP U-Pb detrital zircon data from Negro Peinado Formation (ca. $732 \pm$ $29 \mathrm{Ma})$ and Achavil Formation $(791 \pm 29 \mathrm{Ma})$ from metasedimentary rocks of the Famatina belt (see Collo et al. 2009) are related to Brasiliano I/Early Pan-African. Additional orogenic activity in the Pampia terrane indicates the presence of a vast single Brasiliano/Pan-African-Pampean magmatic arc. Schwartz and Gromet (2004), analyzing detrital zircons in Sierras de Córdoba, for example, indicated a population between $\sim 600$ to $700 \mathrm{Ma}$, representative of Brasiliano II and Main Pan-African orogenic cycle. Late Neoproterozoic to Cambrian ages are widespread in the Pampia terrane as magmatic and metamorphic ages; e.g. Schwartz et al. (2008), Chernicoff et al. (2012), Collo et al. (2009), and, Lork et al. (1989). Metamorphic peaks in the Brasiliano/Pan-African cycles (Silva et al. 2005) are five: $840-800 \mathrm{Ma}$; 730-700 Ma; 640-620 Ma; 590-560 Ma; 520$500 \mathrm{Ma}$. Four of these peaks correlate with this investigation in Iraí zircons, except for the early Neoproterozic ages.
Based on our U-Pb SHRIMP results, we are encouraged to correlate the Pampia orogen with the Brasiliano/Pan-African cycles as a single magmatic arc, supporting the proposition of Chernicoff et al. (2012).

\section{ORDOVICIAN MAGMATISM}

In northwestern Argentina, the Early Cambrian Pampean orogenic belt lies to the west of the Rio de La Plata craton, and was partially overprinted by the Early to Mid-Ordovician Famatinian magmatic arc (Pankhurst et al. 1998, 2006), with intensive deformation in the Late Ordovician. The Famatinian belt (Fig. 2) has been considered as a continental marginal arc related to subduction during the approach and collision of the Precordillera terrane (Pankhurst et al. 2006). The Famatina magmatic arc was formed in a relatively restricted time span around 480 - $470 \mathrm{Ma}$ (Ramos 2000).

The late middle to late Ordovician ages ( 465 $450 \mathrm{Ma}$ ) are compatible with the Cuyania block. This block is considered to have detached from Laurentia and moved towards Gondwana in the Middle to Late Ordovician times, and the time of collision is tracked by the cessation of arc-related magmatic activity in the Gondwana protomargin at about $465 \mathrm{Ma}$ in western Sierras Pampeanas. Ages around $454 \mathrm{Ma}$ correspond to syncollisional and postcollisional magmatism (Ramos 2004).

\section{PERMian Magmatism}

The Permian magmatism corresponds to the Choiyoi volcanic rocks of rhyolitic and dacitic composition associated with shallow level plutons of similar composition (e.g. Mpodozis et al. 1976). Our geochronologic data show that Permian magmatism is very extensive in time and space, concordant with observations made in La Pampa province and North Patagonian Massif (Pankhurst et al. 2006). The oldest age is $295 \pm 5 \mathrm{Ma}$ and the youngest is $244 \pm 6 \mathrm{Ma}$ (Lower Triassic).

Pankhurst et al. (2006) attributed the more voluminous and widespread nature of this magmatism to 
major access of heat to the crust following breakoff of the subducted slab after a continental collision that was initiated in Carboniferous times.

\section{CONCLUSIONS}

The absence of wind-blown, high-angle stratification in the sand extrudite and the absence of detrital zircon ages younger than the Permian that would have originated in the $800 \mathrm{~m}$-thick basaltrhyodacite sequence, makes it very unlikely that the quartz sand deposited in a paleoerg dune. Sand injection from the underlying Botucatu Formation paleoerg is the preferred interpretation.

Our data corroborate the measured direction of sediment transport in aeolian sandstones of the Botucatu Formation (Early Cretaceous of the Paraná Basin) based on cross-strata dip directions. These indicate palaeowind directions from southwest to west $(\mathrm{SW} / \mathrm{W})$. These particularly explain the robust presence of Mesoproterozoic, Permian and Ordovician magmatic populations. There is no register in the detrital zircons of Trans-Amazonian ages ( 2.05 to $2.3 \mathrm{Ga})$ typical of the Tandilla belt (Argentina) and Piedras Altas terrane (Uruguay), corroborating this premise.

1. The Neoproterozoic to Early Cambrian ages suggest an uninterrupted development of arc magmatism on the Pampia terrane from Brasiliano-Pan-African to Pampean times (applying the proposed model of Chernicoff et al. 2012), as indicated by the occurrence of numerous zircon ages of detrital, magmatic and metamorphic ages.

2. The few zircons from Neo-Archean and Paleoproterozoic terranes indicate that the Trans-Amazonian block was poorly exposed when the Botucatu Formation paleoerg was deposited. The Paleoproterozoic crust was intensely reworked in Brasiliano orogenic times.

3. The Permian ages are similar to the ages obtained on zircons from tonsteins in the
Paraná Basin, which originated from ash-fall deposits from intense volcanism in Argentina.

\section{ACKNOWLEDGMENTS}

This work was supported by Programa de Apoio a Projetos de Excelência (PRONEX) project Fundação de Amparo à Pesquisa do Estado do Rio Grande do Sul (FAPERGS)/Conselho Nacional de Desenvolvimento Científico e Tecnológico (CNPq) on "Evolução estrutural e composicional de minerais estratégicos do sul do Brasil", and a UNIVERSAL/ CNPq project, all coordinated by Léo A. Hartmann. The first author thanks for his scholarship from $\mathrm{CNPq}$ both in Brazil and Australia, and acknowledges overall support from the Universidade Federal do Rio Grande do Sul in Brazil and from the University of Western Australia. SHRIMP laboratory is a consortium of The University of Western Australia, Curtin University of Technology and the Geological Survey of Western Australia.

\section{RESUMO}

A determinação de idade, com microssonda iônica, de 102 cristais detríticos de zircão de um extrudito de areia, província vulcânica Paraná, estabelece limites sobre a origem das numerosas camadas de areia presentes nesta grande província de derrames basálticos. As idades $\mathrm{U}-\mathrm{Pb}$ em zircão refletem quatro principais ciclos orogênicos: Mesoproterozóico (1155-962 Ma), final do Neoproterozóico ao início do Cambriano (808-500 Ma) e dois Paleozóicos (Ordoviciano - 480450 Ma, e Permiano a Triássico Inferior - 296 a $250 \mathrm{Ma}$ ). Duas outras pequenas concentrações estão presentes no Neoarqueano (2,8 a 2,6 Ga) e Paleoproterozóico (2,0$1,7 \mathrm{Ga}$ ). Picos de idades de zircão coincidem com os pulsos de vários eventos ígneos no Escudo Brasileiro pré-cambriano e orogenia ativa na Argentina. Uma importante delimitação da origem da areia é a ausência de idades de zircão proveniente dos basaltos cretáceos subjacentes, apoiando assim uma origem de injeção da areia como um extrudito que emanou do paleoerg que constitui a Formação Botucatu. 
Palavras-chave: Formação Botucatu, Brasil, idades Neoarqueanas a Paleozóicas, proveniências, extrudito de areia, idades U-Pb de Zircão.

\section{REFERENCES}

BAHLBURG H AND Hervé F. 1997. Geodynamic evolution and tectonostratigraphic terranes of Northwestern Argentina and Northern Chile. Geol Soc Amer Bull 109: 869-884.

Bigarella JJ AND SALAMUNi R. 1961. Early Mesozoic wind patterns as suggested by dune bedding in the Botucatu sandstone of Brazil and Uruguay. Geol Soc Amer Bull 72: 1089-1106.

CABY R. 1998. Tectonic history and geodynamic evolution of Northern Africa during the Neoproterozoic, in $14^{\text {th }}$ International Conference on Basement Tectonics, Ouro Preto, p. 72-75.

CAmpos Neto MC. 2000. Orogenic systems from southwestern Gondwana. In: Cordani UG, Milani EJ, Thomaz Filho A and Campos DA (Eds), Tectonic Evolution of South America, p. 355-365.

Casquet C, Pankhurst RJ, Fanning M, Baldo E, Galindo C, RAPEla C, GonZaiez-CASAdo JM AND DAHLQUIST JA. 2006. U-Pb SHRIMP zircon dating of Grenville metamorphism in Western Sierras Pampeanas (Argentina): Correlation with the Arequipa-Antofalla craton and constraints on the extent of the Precordillera Terrane. Gondw Res 9: 524-529.

CHEMALE JR F. 2000. Evolução Geológica do Escudo Sul-RioGrandense. In: Holz M and De Ros LF (Eds), Geologia do Rio Grande do Sul: Porto Alegre, Brazil: Editora UFRGS, p. 13-52.

Chemale Jr F, Philipp RP, Dussin I, Formoso MLL, KAWASHITA K AND BERTTOTTI AL. 2011. Lu-Hf and U-Pb age determination of the Capivarita Anorthosite, Dom Feliciano belt, RS, Brazil: Precam Res 186: 117-126.

Chernicoff CJ, Zappettini EO, SAntos JOS, Belousova E AND MCNAUGhTON NJ. 2011. Hf isotope determinations on Paleozoic metaigneous rocks in La Pampa province. Implications for the occurrence of juvenile Early Neoproterozoic (Tonian) magmatism in south-central Argentina. J S Amer Ea Sci 32: 477-484.

Chernicoff CJ, ZAPPETTINI EO, SANTOS JOS, GODEAS MC, BELOUSOVA E AND MCNAUGHTON NJ. 2012. Identification and isotopic studies of early Cambrian magmatism (El Carancho Igneous Complex) at the boundary between Pampia terrane and the Río de la Plata craton, La Pampa province, Argentina. Gondw Res 21: 378-393.

Collo G, Astini R, Cawood PA, Buchan C and Pimentel M. 2009. U-Pb detrital zircon ages and $\mathrm{Sm}-\mathrm{Nd}$ isotopic features in low-grade metasedimentary rocks of the Famatina belt: implications for late Neoproterozoic-early Palaeozoic evolution of the proto-Andean margin of Gondwana. J Geol Soc 166: 303-319.

COMPSTON W, WILLIAMS IS, KIRSCHVINK JL, ZICHAO Z AND GuOGAN M. 1992. Zircon ages for the Early Cambrian timescale. J Geol Soc Lond 149: 171-184.
Cordani UG, Coutinho JMV AND Nutman A. 2002. Geochronological constraints for the age of the Embu Complex, São Paulo, Brazil. J S Amer Ea Sci 14: 903-910.

Escayola MP, Pimentel MM AND ARmstrong R. 2007. Neoproterozoic backarc basin: Sensitive high-resolution ion microprobe $\mathrm{U}-\mathrm{Pb}$ and $\mathrm{Sm}-\mathrm{Nd}$ isotopic evidence from the Eastern Pampean Ranges, Argentina. Geology 35: 495-498.

FEDo CM, SiRCOMBE KN AND RAINBIRD RH. 2003. Detrital zircon analysis of the sedimentary record. In: Hanchar JM and Hoskin PWO (Eds), Rev Mineral Geoch 53: 277-303.

FRANK HT, GOMES MB AND FORMOSO ML. 2009. Review of the areal extend and the volume of the Serra Geral Formation, Paraná Basin, South America. Pesquisas 6: 49-57.

Guerra-Sommer M, CAZZulo-KLePzig M, SANTos JOS, HARTMANN LA, KetZer JM AND FORMOSO MLL. 2008. Radiometric age determination of tonstein and stratigraphic constrains for the Lower Permian coal succession in southern Paraná Basin, Brazil: Intern J Coal Geol 74: 13-27.

HARTMANN LA, ARENA KR AND DUARTE SK. 2012. Geological relationships of basalts, andesites and sand injectites at the base of the Paraná volcanic province, Torres, Brazil. J Volcanol Geoth Res 237-238: 97-111.

HARTMANN LA, BAGGIO SB AND DUARTE SK. 2013. Decoding geochemical and gamma-spectrometric signatures from lavas and sand injectites at the base of the Paraná volcanic province, Novo Hamburgo, Brazil. Intern Geol Rev 55: 510-524.

HARTMANN LA, LEITE JAD, SilVA LC, REMUS MVD, MCNAUGHTON NJ, GROVES DI, FLETCHER IR, SANTOS JOS AND VASCONCELLOS MAZ. 2000. Advances in SHRIMP geochronology and their impact on understanding the tectonic and metallogenic evolution of southern Brazil. Austr J Ea Sci 47: 829-843.

Hartmann LA, PhilipP RP, LIU D, WAN Y, WANG Y, SANTOS JOS AND VASCONCELLOS MAZ. 2004. Paleoproterozoic magmatic provenance of detrital zircons, Porongos Complex quartzites, southern Brazilian shield. Intern Geol Rev 46: 127-157.

HARTMANN LA AND SANTOS JOS. 2004. Predominance of high $\mathrm{Th} / \mathrm{U}$, magmatic zircon in Brazilian shield sandstones. Geology 32: 73-76.

HARTMANN LA, SANTOS JOS AND MCNAUghton NJ. 2008. Detrital zircon U-Pb age data, and Precambrian provenance of the Paleozoic Guaritas Formation, southern Brazilian Shield. Intern Geol Rev 50: 364-374.

JANASI VA, FreITAS VA AND HEAMAN LH. 2011. The onset of flood basalt volcanism, Northern Paraná Basin, Brazil: A precise U-Pb baddeleyite/zircon age for a Chapecó-type dacite. Ea Planet Sci Lett 302: 147-153.

Lork A, Miller H AND Kramm U. 1989. U-Pb zircon and monazite ages of the La Angostura granite and the orogenic history of the northwest Argentine basement. J S Am Ea Sci 2: $147-153$.

LUDWIG KR. 1999. Using ISOPLOT/Ex, version 2: a geochronological toolkit for Microsoft 251 Excel. Berkeley Geochronological Center Sp. Publ. Ia, 47 p. 
LUDWIG KR. 2002. Squid 1.02, a user's manual. Berkeley Geochronological Center Sp. Publ., 2. Berkeley, California, USA, $21 \mathrm{p}$.

Moore GT, HaYashida DN, Ross CA AND JACOBSON SR. 1992. Palaeoclimate of the Kimmeridgian/Tithonian (Late Jurassic) world. I. Results using a general circulation model. Pelaeog Palaeoclim Palaeoecol 93: 113-150.

MPODOZIS C, PARADA MA, Rivano S AND ViCENTE JC. 1976 Acerca del plutonismo tardi-hercínico de la Cordillera Frontal entre lós $30^{\circ}$ y $33^{\circ}$ Sur (Provincias de Mendoza y San Juan - Argentina ; Coquimbo - Chile): $6^{\circ}$ Congreso Geológico Argentino (Bahía Blanca), Actas 1: 143-171.

NAJMAN Y. 2006. The detrital record of orogenesis: A review of approaches and techniques used in the Himalayan sedimentary basins. Ea-Sci Rev 74: 1-72.

PANKHURST RJ, RAPELA CW, FANNING CM AND MÁRQUEZ M. 2006. Gondwanide continental collision and the origin of Patagonia. Ea-Sci Rev 76: 235-257.

PANKHURST RJ, RAPElA CW, SAAVEdRA J, BALdo E, DAHLQUIST J, PASCUA I AND FANNING CM. 1998. The Famatinian magmatic arc in the Central Sierras Pampeanas: an early to mid-Ordovician continental arc on the Gondwana margin. In: Pankhurst RJ and Rapela CW (Eds), The ProtoAndean Margin of Gondwana. Geol Soc Lond Sp Pub 142: 343-367.

Peate DW, Hawkesworth CJ AND Mantovani MSM. 1992. Chemical stratigraphy of the Paraná lavas (South America): classification of magma types and their spatial distribuition. Bull Volcanol 55: 119-139.

PINTO VM AND HARTMANN LA. 2011. Flow-by-flow chemical stratigraphy and evolution of thirteen Serra Geral Group basalt flows from Vista Alegre, southernmost Brazil. An Acad Bras Cienc 83: 425-440.

Pinto VM, HaRtmann LA, Santos JOS, McNaughton NJ AND WILDNER W. 2011. Zircon U-Pb geochronology from the Paraná bimodal volcanic province support a brief eruptive cycle at $\sim 135 \mathrm{Ma}$. Chem Geol 281: 93-102.

RAmos VA. 2000. The southern Central Andes, In: Cordani UG, Milani EJ, Thomaz Filho A and Campos A (Eds), Tectonic Evolution of South America, 31 ${ }^{\text {st }}$ Int. Geol. Cong., Rio de Janeiro, p. 561-604.

RAmos VA. 2004. Cuyania, an exotic block to Gondwana: review of a historical success and the present problems. Gondw Res 7: 1009-1026.

RAmos VA, VuJOVICH G, MARTINO R AND OtAMENDI J. 2010. Pampia: a large cratonic block missing in the Rodinia supercontinent. J Geodyn 50: 243-255

Rapela CW, Fanning CM, Casquet C, Pankhurst RJ, Spalletti L, Poiré D And Baldo E. 2011. The Rio de la Plata craton and the adjoining Pan- African/Brasilian terranes: Their origins and incorporation into south-west Gondwana. Gondw Res 20: 673-690.

SANTOS JOS, HARTMANN LA, BOSSI J, CAMPAL N, SCHIPILOV A, PiÑEYro D AND MCNAughton NJ. 2003. Duration of the Trans-Amazonian Cycle and correlation within South America based on U-Pb SHRIMP geochronology of the La Plata Craton, Uruguay. Int Geol Rev 45: 27-48.
SANTOS JOS, HARTMANN LA, MCNAUGHTON NJ, EASTON RM, REA RG AND POTTER PE. 2002. Sensitive high resolution ion microprobe (SHRIMP) detrital zircon geochronology provides new evidence for a hidden Neoproterozoic foreland basin to the Grenville Orogen in the eastern Midwest, U.S.A. Can J Ea Sci 39: 1505-1515.

SCHERER CMS. 2000. Aeolian dunes of the Botucatu Formation (Cretaceous) in Southernmost Brazil: morphology and origin. Sediment Geol 137: 63-84.

SCHERER CMS AND GOLDBERG K. 2007. Paleowind patterns during the latest Jurassic-earliest Cretaceous in Gondwana: Evidence from aeolian cross-strata of the Botucatu Formation, Brazil. Palaeog Palaeoclim Palaeoecol 250: 89-100

SchwARTZ JJ AND GROMET LP. 2004. Provenance of Late Proterozoic-early Cambrian basin, Sierras de Córdoba, Argentina. Precam Res 129: 1-21.

SCHWARTZ JJ, GROMET LP AND MIRÓ R. 2008. Timing and duration of the calc-alkaline arc of the Pampean Orogeny: implications for the Late Neoproterozoic to Cambrian evolution of Western Gondwana, J Geol 116: 39-61.

Silva LC, MCNAUghton NJ, ARMSTRONG R, HARTMANN LA AND FLETCHER IR. 2005. The neoproterozoic Mantiqueira Province and its African connections: a zircon-based U$\mathrm{Pb}$ geochronologic subdivision for the Brasiliano/PanAfrican systems of orogens. Precam Res 136: 203-240.

SMith JB, BARley ME, Groves DI, KrapeZ B, MCNAUGHTON NJ, BICKLE MJ AND CHAPMAN HJ. 1998. The Scholl shear zone, West Pilbara: Evidence for a terrane boundary structure from integrated tectonic analyses, SHRIMP U/ $\mathrm{Pb}$ dating and isotopic and geochemical data of granitoids. Precam Res 88: 143-171.

Stanistreet IG AND StOllhoffen H. 1999. Onshore equivalents of the Kudu gas reservoir in Namibia. In: Cameron NR, Bate RH and Clure VS (Eds), The Oil and Gas Habitats of the South Atlantic. Geol Soc Lond Sp Pub 153: 345-365.

THIEDE DS AND VASCONCELOS PM. 2010. Paraná flood basalts: rapid extrusion hypothesis confirmed by new $40 \mathrm{Ar}-39 \mathrm{Ar}$ results. Geology 38: 747-750.

ZALÁN PV, WOLF S, CONCEIÇÃO JC, ASTOLFÍ AM, VIEIRA IS, APPI VT, ZANOTTO OA AND MARQUES A. 1991. Tectonics and sedimentation of the Paraná Basin, In: Ulbrich HHGJ and Rocha-Campos AC (Eds), Gondwana Seven. São Paulo, Inst. de Geoc. da USP, p. 83-117.

\section{SUPPLEMENTARY MATERIAL}

TABLE SI - U-Pb SHRIMP isotopic data from detrital zircons of the studied sand extrudite, sample VIS-1/2, C-D populations; $\mathrm{c}=$ core, $\mathrm{r}=$ rim 